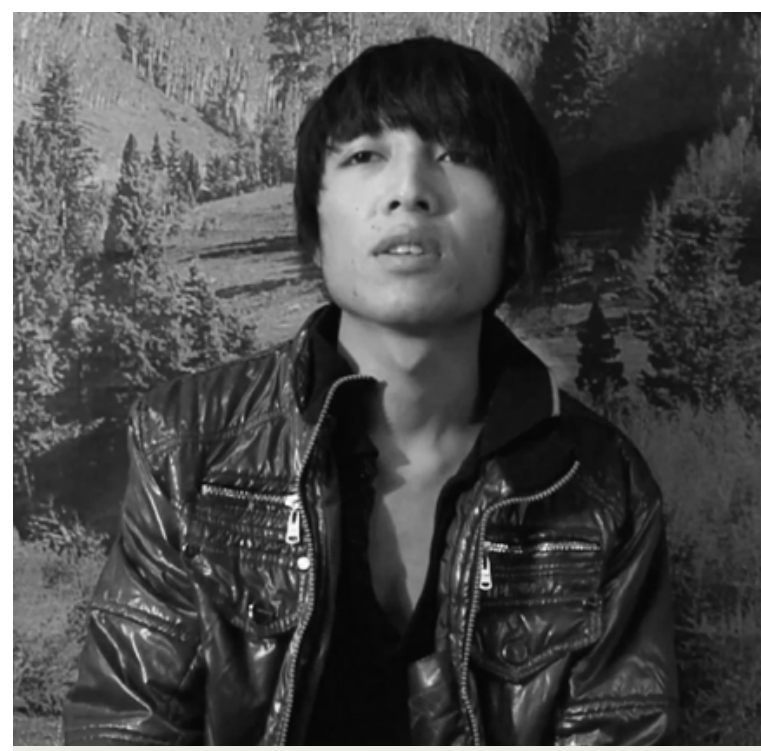

Wu Tingshan, a worker in Shenzhen interviewd for the documentary Dreamwork China in 2011

\section{Chinese Workers and the Law: Misplaced Trust?}

\section{Ivan Franceschini}

In recent years, much has been written about the 'rights awakening' of Chinese workers. But what kind of rights are we talking about? Do they respond to an entirely subjective concept of justice or do they somehow coincide with the entitlements provided by the labour legislation? On the basis of a survey carried out among 1,379 employees of Italian metal mechanic companies in China, this article will attempt to answer three key questions: how do Chinese workers perceive the labour contract? How much do they know about labour legislation and how does this knowledge affect their trust of the law? What do they think about going on strike as a strategy to protect their rights?

A fuller set of data can be found in the author's book: Lavoro e diritti in Cina: Politiche sul lavoro e attivismo operaio nella fabbrica del mondo (Labour and rights in China: Labour policies and worker activism in the world factory), Il Mulino, Bologna, 2016.
One fascinating question concerning labour activism in contemporary China regards the attitude of Chinese migrant workers towards the law. In recent years, much has been written about the 'rights awakening' (quanli de juexing) of Chinese workers. But what kind of rights are we talking about? Do they respond to an entirely subjective concept of justice or do they somehow coincide with the entitlements provided by the labour legislation? And what is the relationship that binds legal awareness (falü yishi), rights consciousness (quanli yishi), and solidarity (tuanjie yishi)? That these elements do not necessarily go hand in hand is highlighted by the following testimony by a labour activist whom I interviewed in Shenzhen in 2014:

If ten [young migrants] come to me saying that their rights have been violated, they usually want to sue the company, but don't know how. Although I suggest that they sue the company together, they generally choose to do it separately. I don't think of this as a contradiction. If legal consciousness and solidarity consciousness are so low, how can they have such a high awareness of rights protection (weiquan yishi)? For example, if one of their fathers had his rights violated, he would choose to stay silent. If the son has his rights violated, he will explode and fight. If he didn't sign a labour contract and gets fired, he will ask for double wage as compensation. But they don't know anything about these compensations, they only know that their bosses have deceived them.

[Interview, Shenzhen, October 2014]

It is with these and other questions in mind that a few years ago I undertook a survey among the employees of nine Italian metal mechanic factories (either joint ventures or wholly foreign owned enterprises) in three Chinese cities: Shenzhen, Yangzhou, and Chongqing. In three rounds of interviews-respectively in 2012, 2014, and 2015- I was able to conduct 1,379 questionnaires at the gates of the 
various factories, without any knowledge or interference by the management. The workers in my sample were mostly men (74.2 per cent); 24.5 per cent of them were born before 1980 , 45.4 per cent in the Eighties, and 30.1 per cent in the Nineties; and their educational level was medium-high, with 32.7 per cent of the workers having graduated from middle school, 22.1 per cent from high school, 20.2 per cent from middle technical school, and 18.9 per cent from higher technical school.

Were all these workers migrants? Actually, only 63.7 per cent of the respondents had a rural household registration (nongye hukou), the traditional parameter to determine a worker's status as an internal migrant. Still, taking the hukou as a parameter that defines the identity of Chinese workers today may be quite treacherous, as many 'urban' employees of the factories in Chongqing and peri-urban Yangzhou were local farmers whose status had been 'upgraded' following the new policies of forced urbanisation adopted by the local authorities. Similarly, only thirty-three per cent of the workers came from a different province-with the significant exception of Shenzhen, where only 11.3 per cent of the workers were from Guangdong-a finding that mirrors the growing importance of intraprovincial migrations in China.

In my survey, I attempted to measure the awareness of these workers regarding some key aspects of labour law, as well as their expectations towards wages and work hours. Yet in this article I will focus on three questions: how do Chinese workers perceive the labour contract? How much do they know about labour legislation and how does this knowledge affect their trust of the law? What do they think about going on strike as a strategy to protect their rights?

\section{Labour Contracts}

At the cornerstone of the discourse of the party-state on 'harmonious labour relations' (hexie laodong guanxi), labour contracts can provide some interesting insights on the way Chinese workers relate to the labour law and the relevant propaganda. 97.2 per cent of the workers in my survey had signed an individual labour contract, a clear proof of the commitment of the authorities to enforce the labour contract system, at least in the industry I considered (in other sectors, for instance the construction sector, the rate is remarkably lower, and according to official data from the National Bureau of Statistics in 2015 only 36.2 per cent of all migrant workers had signed a labour contract with their employer). But how many workers believed in the importance of the contract as an instrument to protect their rights? A question I asked is whether the workers had read the clauses of the contract before signing it. Only 26.7 per cent of them had read them carefully (zixi yuedu), while 46.5 per cent just had had a quick look (suibian kan), and 26.8 per cent had signed without reading (qianming eryi). This seems to display a certain disinterest in the labour contract, as if it were an irrelevant piece of paper. Yet, when directly asked whether they considered contracts as an effective tool to protect their rights, 22.3 per cent of the workers responded affirmatively (keyi) and 49.2 per cent was relatively optimistic (hai keyi), compared with only 7.3 per cent who expressed disbelief (bu keyi), and 21.2 per cent who did not know how to answer. In essence, almost two thirds of the workers trusted the capacity of labour contracts to protect them.

I then asked whom they thought was the main beneficiary of a labour contract. Although the Labour Contract Law that came into force in 2008 is rather favourable to workers when it comes to the resolution and severance of labour relations, somehow unsurprisingly 82.5 per cent of the respondents believed that a labour contract benefitted both employer and employee, while only 3.5 per cent declared that the worker was the one to benefit the most. Still, there was a significant minority of workers (12.8 per cent) who believed that the 
labour contract benefitted only the company. This was because in the eyes of some workers a labour contract is a significant restraint to mobility, and mobility-i.e. 'voting with your feet' (yi jiao toupiao)-often is the only way to resist corporate exploitation. As a migrant worker whom I interviewed in 2011 for the documentary Dreamwork China said:

A contract? It is like this: if you sign it, you cannot leave for the next three months. If you don't sign it, you can leave whenever you want, even before a month. If it is an annual contract, you have to work for at least three months or you cannot quit. This is the labour contract. [Interview, Shenzhen, January 2011]

\section{Legal Knowledge and Trust towards the Law}

This relative confidence in labour contracts opens some further questions about how Chinese workers perceive the labour law. Without going into too much detail, I found that the workers in my sample to have a selective knowledge of the provisions of the labour legislation, exemplified by the 1995 Labour Law and the 2008 Labour Contract Law. In particular, they were very aware of clauses that affected their direct economic interests-such as those that regulate the way overtime wages are calculated (90.6 per cent of the workers were aware)-while knowing very little about other aspects of the labour legislation, which they probably perceived as less relevant to their income. For instance, just 17.5 per cent of the workers knew that they were supposed to work no more than thirtysix hours of overtime a month. Similarly, only 25.1 per cent of the workers could write down the correct local minimum wage (on the whole, though, I found that the higher a worker's basic wage, the less likely he/she is to know the correct minimum wage). Even more important, I found a clear divide between the knowledge of individual rights-generally low but still existing-and that of collective rights. Many workers had no clear idea about what a trade union is (11.4 per cent had never heard the word 'trade union' before), and 98.2 per cent of the respondents had no idea of what 'collective negotiation' (jiti xieshang)-the Chinese watered-down version of collective bargaining-was.

In spite of (or maybe due to) this highly selective knowledge, when I asked the workers whether they believed that the existing labour legislation was able to protect them, most of them were quite optimist. 5.7 per cent were absolutely sure that it could (wanquan neng) and 49.6 per cent were slightly less sure, but still quite positive about it (yinggai keyi). On the contrary, 34.1 per cent were dubious (yexu neng) and 10.5 per cent were definitely sceptical (bu neng). If these results display a considerable confidence in the law, it is interesting that this perception does not derive from a personal experience with the Chinese legal system. In fact, only 3.3 per cent of the workers in the sample had dealt with a labour dispute by legal means before. This apparently confirms what Mary Gallagher and Yuhua Wang found out in a previous study, that 'non-users [of the legal system] tend to have vague but benevolent notions of the legal system and its effectiveness' (Gallagher and Wang 2011, 204).

\section{Perception of Strikes}

How do strikes figure within such a 'benevolent notion' of the legal system? My survey shows that trusting the law and resorting to strikes are not necessarily mutually exclusive. While China has ratified the International Covenant on Economic, Social, and Cultural Rights, which at article 8.1 (d) binds the government to ensure the right to strike, provided that it is exercised in conformity with the laws of the particular country', the Chinese legislation does not mention the right to strike at all, consigning 
it to a grey area (Chang and Cooke 2015). Since even Chinese scholars have not reached a conclusion on the legality of industrial actions in China, I therefore did not expect the workers to have a clear idea on this issue. Yet, when I asked them whether they believed that going on strike was legal or illegal, I was surprised to find out that 38.5 per cent of the respondents said that it was legal, compared with only 13.9 per cent who believed the opposite (the rest did not know). That such a high percentage of workers expressed the belief that strikes are legal is quite impressive. It means that many workers in China believe that the law-and therefore the apparatus of the party-state-will support them in the event of a strike. This may be taken as a hint of the extent to which the work of propaganda and legal dissemination undertaken by the Chinese authorities in the past two decades has succeeded.

Still, the idea that going on strike is 'legal' does not mean that Chinese workers are willing to protest at the slightest perceived violation of their rights. The right to strike is often framed by the workers in moral rather than legal terms, as a last resort after all other avenues of redress have failed. As a young respondent said: 'In a situation in which there is no choice other than going on strike, you cannot say that it is illegal. Still, the workers do not want to go on strike without reason' [Interview, Shenzhen, April 2012]. Nevertheless, when I asked what they thought about going on strike as a strategy to protect their rights, 43.3 per cent of the respondents were either favourable or extremely favourable, compared with only 26.8 per cent who were against or absolutely against it (29.8 per cent did not know).

\section{Conclusions}

The data presented in this article show that when discussing the 'rights awakening' of Chinese workers it is important to consider what we mean by the term 'rights'. In particular, more attention should be paid to the way these workers respond to the official discourse on labour rights promoted by the party-state through the labour law and other relevant policy documents. As I have attempted to show, the official discourse is deeply rooted in the mind of the workers in my sample. This can been seen in two respects: the workers' conviction that labour contracts and the labour law can protect them; and their selective knowledge of the labour law provisions, strongly unbalanced towards individual rights with direct economic implications. This 'benevolent notion' of the legal system even affects the perception of strikes, which are considered 'legal' by a very significant portion of the workforce. This means that many Chinese workers believe that the apparatus of the party-state will support them in their decision to go on strike-at least as long as they have a 'reasonable' motivation to do so. If these findings do not provide a definite answer to the wider theoretical questions outlined at the beginning of the article, they nonetheless warrant some further attention when discussing the 'awakening' of the Chinese working class.

\section{Ivan Franceschini}

Ivan Franceschini is a Marie Curie Fellow at Ca' Foscari University of Venice and at the Australian Centre on China in the World working on a project on Chinese labour in a global perspective. From 2006 to 2015, he lived in China, where he worked as a journalist and as a consultant in the field of development cooperation. His research interests focus on Chinese labour and civil society. 
This text is taken from Disturbances in Heaven: A Year of Chinese Labour, Civil Society, and Rights, Made in China Yearbook 2016, edited by Ivan Franceschini, Kevin Lin and Nicholas Loubere, published 2017 by ANU Press, The Australian National University, Canberra, Australia. 